\title{
AN ANALYSIS ON ACCULTURATION BETWEEN ARABIC LANGUAGE AND JAVANESE LANGUAGE IN BULULAWANG, MALANG
}

\author{
Nanik Widiawati \\ Letters Faculty, Kanjuruhan University of Malang \\ Jl. S. Supriadi 48 Malang 65148, East Java, Indonesia \\ Phone (62)857-8550-1298 E-mail: mailto:nanikwid9@ gmail.com \\ Arining Wibowo \\ Letters Faculty, Kanjuruhan University of Malang \\ Jl. S. Supriadi 48 Malang 65148, East Java, Indonesia \\ Phone (0341) 801488 (ext. 341) E-mail: - \\ Trisno Tunggal Rahayu Wilujeng \\ Letters Faculty, Kanjuruhan University of Malang \\ Jl. S. Supriadi 48 Malang 65148, East Java, Indonesia \\ Phone (0341) 801488 (ext. 341) E-mail: trisnotrw@gmail.com
}

\begin{abstract}
Acculturation is a process which is growth and appear if the society face with a new culture. And this new culture influence in their society, so they are adapting from the old culture become as new culture. Concerning with aculturation of islamic and javanese culture it is an interesting term, people not being aware to analyze something closer with their envinronment, something that not be watched and language is one of the interesting term to be anayze. Therefore, the researcher is interested in studying this problem by formulating three research problems: (1) what are the acculturaturation betweeen Arabis language and Javanese language in Bululawang?. (2) what are the meanings of those acculturation? (3) how the process of acculturation between Arabic language and Javanese language in Bululawang?. Hopefully of the findings of the acculturation between Arabic Language and Javanese language, people can catch the language philosophy, they know that some of language that they used is made from the acculturation. And for the younger generations must know well about the process from this acculturation, it can add more knowledge for them.
\end{abstract}

Key words: Acculturation, Arabic Language, Javanese Language

\section{Introduction}

Indonesia is a multicultures country where the cultures grow rapidly in society. According to Indonesia's Motto "Bhineka Tunggal Ika" which meaning is "unity in difersity", from this motto absolutely influence in many field not only in culture, but also in beliefs, tradition, ceremonial, and etc which grow and exist in society. Ferraro (1998: 16) states that culture is shared 
by at least two or more people, and of course real, live societies are always larger than that. In culture, it stands for combination of old culture with new things, it called as acculturation. Graves (1967) used the term psychological acculturation to describe the effects of acculturation at the individual level. This process involves changes that an individual experiences in terms of their attitudes, values, and identity as a result of being in contact with other cultures.

Concerning with aculturation of Arabic languge and javanese language it is an interesting term, people not being aware to analyze something closer with their envinronment, something that not be watched. All of them do not know that a less of their culture is made of aculturation, so that why people must known about their cultural philosophy or cultural tradition.

Language is one of the interesting term to be analyze. Language it can be for the acculturation, for the example, the word apem (one of the traditional food in java ), it is from an Arabic Language afwan ( it means sorry ). The Javanese people addopted the language and used it for an addition to describe a new thing. Apem is one kinds of food which offered in Slametan Ritual. It is used from Muslims for people who passed away to have forgiveness of mistakes. So, the javanese people take the word to describe something.

Arabic language $\longrightarrow$
Javanese Language
$\quad$ Afwan
apem

The word apem represents for having a pardon. Actually is used in one of ceremony for completing the slametan ritual. So, languange and Islamic are closely related. Languange it can be as a symbols to represent something.

\section{Methods}

In conducting this study, the researcher uses qualitative research. in the qualitative research, the measurement deal with words. They take data by interviewing, taking field notes and others. So does if they want to present data. They take the quotation as the prove. In addition, the researcher tends to present as closely as posible in the form which they are recorded.

This research descriptive research can go well with survey, the specific design. Survey is a method of sociological investigation that uses question to collect information about how people think and act. For example of survey in the research might involve looking the aculturation probably happen in Bululawang.

For collecting the data, the researcher used four kinds instrumentations, there are :

\section{Observation}

The researcher observes a field of study to the sosiety with observe the environment condition and how to find out about the acculturation between Arabic language and Javanse language probably happen in the society.

\section{Documentation}

Researcher also uses documentation in order to collect the data. Documentation is research instrument to obtain the data concerning with the research subject condition by using recorder to record all of the data. The researcher records pengajian ( listening of the religious expert's sermon ) and transcript it as auto documents.

\section{Corpuses}

Corpuses is a body writing of the researcher. In this research, corpuses 
used a collection data noted by the researcher, such as : the example of conversation in the pengajian. The corpuses on this research is contained the Javanese Language, Arabic language, the acculturation of both of language, and the meaning that can be drawn and explained by using a table.

4. Interview

Interview is used by the researcher to get all the information about acculturation. Interview is instrument to obtain the data concerning with the research subject condition by using oral interaction between the researcher as interviewer.

\section{FINDINGS AND DISCUSSION}

The result of this research found words that contain acculturation of Arabic language and Javanese language. These words are used in conversation in daily life, but people are not being aware about this condition. After recording pengajian and transcript it into text, the researcher find the data which are related in form of acculturation between Arabic Language and Javanese language are as follows :

\section{Datum 1 on $1^{\text {st }}$ Transcript}

"Para bapak ibuk kawulo hormati sakmeniko kabeh sederek saking nyambut bulan sya'ban, tanggal 5 bulan sya'ban. sehubungan kalian bulan sya'ban mugimugi kito angsal barokah barokahe bulan sya'ban bulan rejeb manton niki bulan romadhon".

These italic words are the acculturation of Arabic langauge with Javanese language with each meanings are :

- Sya'ban : Month of Islam,

- Barokah : blessing
- Rejeb : Month of

Islam, consists of Syawal, Selo, Besar, Suro, Sapar,

Mulud, Ba'do Mulud,

Madilawal, Madilakhir,

Rejeb, Ruwah, Poso.

- Romadhon : Month of Islam, usually called as poso.

These acculturation is from Arabic words as the original language :

- Sya'ban : Sya'banu

- Barokah : Barokatu

- Rejeb : Rojabun

- Romadhon

Ramadloni

\section{Datum 2 on $1^{\text {st }}$ Transcript}

"Inggih meniko lan panjenengan sedoyo diparingi barokah, umur kito barokah, rejekine kito barokah, mugi ilmu-ilmune kito barokah kangge persiapan menghadapi bulan romadhon. Para bapak ibu engkang kulo hormati eng dalem bulan sya'ban niki kanjeng nabi pernah ing malem nisfu sya'ban malaikat Jibril marani kanjeng nabi”.

These italic words are the acculturation of Arabic langauge with Javanese language with each meanings are :

- Ilmu

knowledge, science

- Nisfu Sya'ban: Nisfu is half of, and Sya'ban is month of Islam. Nisfu Sya'ban is a half of Sya'ban, means at 15 th day of Sya'ban.

These acculturation is from Arabic words as the original language : 
- Ilmu : 'Ilmi
- Nisfu Sya'ban : Nisfu
Sya'ban

Datum 3 on $1^{\text {st }}$ Transcript

"Rohmate Allah niku wonten sangang poloh songo mbenjeng diparengaken ten akhirat. Dadi welas e Allah mek sitok rahmat iki dirasakno gae menungso lan mahluk sak alam dunyo. Sampek menawi ono jenenge tafsir al azhar".

These italic words are the acculturation of Arabic langauge with Javanese language with each meanings are :

- Rohmat/rahmat affection

- Tafsir explanation/interpretation

These acculturation is from Arabic words as the original language :

- Rohmat/rahmat

Rahmatu

- Tafsir

Tafsiru

\section{Datum 4 on $1^{\text {st }}$ Transcript}

"Dadi kemusyrikan mboten namung ngarani gusti Allah loro tapi dengan keyakinan seng model koyog ngunuku ndadekno musyrik".

These italic words are the acculturation of Arabic langauge with Javanese language with each meaning is :

- Musyrik

Comparing Allah with anyone else

These acculturation is from Arabic words as the original language :

- Musyrik : Musyriki

\section{Datum 5 on $1^{\text {st }}$ Transcript}

"Pak niki rodaqoh
njenengan dungaaken
slamet, lek gak popo
timbang diculno dijembatan
lak eman yo. Kekno uwong
sodaqoh nggeh a?"

These italic words are the acculturation of Arabic langauge with Javanese language with each meanings are :

- Slamet : safety, salvation

- Sodaqoh : giving something to the poor in the name of Allah

These acculturation is from Arabic words as the original language :

- Slamet : Salamatu

- Sodaqoh : Sodaqoti

\section{Datum 6 on $1^{\text {st }}$ Transcript}

"Dadi monggo istighfar
muni bismillah golek
perlindungan".

These italic words are the acculturation of Arabic langauge with Javanese language with each meaning is :

- Istighfar : make a pardon

- Bismillah : On the name of God

These acculturation is from Arabic words as the original language :

- Istighfar : Istighfar

- Bismillah : Bismillah

\section{Datum 7 on $1^{\text {st }}$ Transcript}

"Tiyang seng ngelanjutno minum khomer, ngelanjutno narkoba".

These italic words are the acculturation of Arabic langauge with Javanese language with each meaning is :

- Khomer : kinds of beverage which an intoxicate 
These acculturation is from Arabic words as the original language :

\section{- Khomer : Khomru}

\section{Datum 8 on $1^{\text {st }}$ Transcript}

"Mangkane iku berbahaya, mugi-mugi iso adoh seng nggarai mesjid cek sepi langgar cek sepi."

These italic words are the acculturation of Arabic langauge with Javanese language with each meaning is :

- Mesjid/masjid : mosque

These acculturation is from Arabic words as the original language :

- Mesjid/masjid : Masjidi

\section{Datum 9 on $1^{\text {st }}$ Transcript}

"Mukhsiron ala zina, wong seng selalu zino, niki mboten katut, zino awan bengi awan bengi iku mboten katut oleh pengapurane Allah. $\mathrm{Al}$ aqilal riba', seng mboten katot maleh wong seng engkang riba', riba' niki ngge ngonten wes meraja lela."

These italic words are the acculturation of Arabic langauge with Javanese language with each meanings are :

- Zino : sex without marriage

- Riba' : interest

These acculturation is from Arabic words as the original language :

- Zino : Az-zina

- Riba' : Ar-riba'

\section{Datum 10 on $1^{\text {st }}$ Transcript}

"Lha sembahyang e niki mboten wonten seng njelasake niki sembahyang iki sembahyang nopo, yo pokok sembahyang sunnah, seng utama lek pas nang masjid iki sembahyang takhiyatul masjid. Terus lek waktun bengi yo tahajud, terus mantun ngoten sembahyang tasbeh, sembahyang tobat. Sembahyang tasbeh niku sekawan rokaat."

These italic words are the acculturation of Arabic langauge with Javanese language with each meanings are :

- Sunnah : additional of reward

- Rokaat : number of ritual prayers

These acculturation is from Arabic words as the original language :

- Sunnah : : Sunnatun

- Rokaat : Rokaatin

\section{Datum 11 on $1^{\text {st }}$ Transcript}

"Lek malem nisfu sya'ban sholat nopo ? damel ngaji ? yo gakpopo tapi yo ono sholat e. Damel sholat tasbeh ngoten."

These italic words are the acculturation of Arabic langauge with Javanese language with each meaning is :

- Sholat tasbeh : prayer beads

These acculturation is from

Arabic words as the original language :

- Sholat tasbeh : Sholatuttasbik

\section{Datum 12 on $1^{\text {st }}$ Transcript}

"Lajeng sholat tobat seng

koyog sembahyang dhuhur

rokaat awal ba'da

fatekhah qulya peng

sewelas lajeng rokaat

nomer kale $b a$ 'd $a$ fathehah qulhu peng sewelas."

These italic words are the acculturation of Arabic langauge with Javanese language with each meaning is : 
- Sholat tobat : prayer for regret an exclamation

These acculturation is from Arabic words as the original language :

- Sholat tobat :

Sholatuttaubati

\section{Datum 13 on $1^{\text {st }}$ Transcript}

"Lek due tasbeh guede yo semngat, tapi lek diwoco karo sholat mboten keroso."

These italic words are the acculturation of Arabic langauge with Javanese language with each meanings are :

- Tasbeh : (n) tool for praying

- Sholat : moslem prayer (at least 5 times a day)

These acculturation is from Arabic words as the original language :

$$
\begin{aligned}
& \text { - Tasbeh : Tasbikhun } \\
& \text { - Sholat : Shollatun }
\end{aligned}
$$

\section{Datum 14 on $1^{\text {st }}$ Transcript}

'Ruku' peng sedoso,

duduk diantara dua sujud peng sedoso"

These italic words are the acculturation of Arabic langauge with Javanese language with each meanings are :

- Ruku' : one kinds of movement in praying, hump the body and the hand holds into knees.

- Sujud : one kinds of movements in praying, put th forehead down into the ground.

These acculturation is from Arabic words as the original language :

$$
\begin{aligned}
& \text { - Ruku' : Ruku'un } \\
& \text { - Sujud : Sujudi }
\end{aligned}
$$

Datum 15 on $1^{\text {st }}$ Transcript

"Lajeng sholat tobat seng koyog sembahyang dhuhur."
These italic words are the acculturation of Arabic langauge with Javanese language with each meaning is :

- Dhuhur : midday prayer

These acculturation is from Arabic words as the original language :

\section{- Dhuhur : Dhuhri}

\section{Datum 16 on $1^{\text {st }}$ Transcript}

"Akhire kan maleh ngeten untung aku wes iso jamaah maghrib dari pada aku ora tau."

These italic words are the acculturation of Arabic langauge with Javanese language with each meaning is :

- Jamaah : together

These acculturation is from Arabic words as the original language :

$$
\begin{aligned}
& \text { - Jamaah : Jama'atun } \\
& \text { Datum } 17 \text { on } 1^{\text {st }} \text { Transcript } \\
& \text { "ziaroh nang bapakne ae ga } \\
& \text { iso ziaroh wong tuwo, } \\
& \text { ziaroh pesareane wong } \\
& \text { tuwo." }
\end{aligned}
$$

These italic words are the acculturation of Arabic langauge with Javanese language with each meaning is :

$$
\text { - Ziaroh : visiting }
$$

These acculturation is from

Arabic words as the original language :

$$
\text { - Ziaroh : Dziarotun }
$$

\section{Datum 18 on $1^{\text {st }}$ Transcript}

"Sebab dengan benar-benar kito sampun dapet ampunan romadhon diterusaken maneh oleh tobat oleh mateng-matengno ibadah sehinggo sedoyo duso-duso kito dingapuro."

These italic words are the acculturation of Arabic langauge with Javanese language with each meaning is : 
- Ibadah : following order and leaving prohibition

These acculturation is from Arabic words as the original language :

$$
\text { - Ibadah : 'Ibadatun }
$$

\section{Datum 19 on $2^{\text {nd }}$ Transcript}

"Poro ulama, poro kyai inkang kulo mulyaaken mugi dumateng khabibbahdi beserta ulil lan poro kyaikyai ingkang rawuh."

These italic words are the acculturation of Arabic langauge with Javanese language with each meanings are :

$$
\text { - Ulama : religious }
$$

These acculturation is from Arabic words as the original language :

$$
\text { - Ulama : Ulama'u }
$$

\section{Datum 20 on $2^{\text {nd }}$ Transcript}

"Sedoyo takmir ketum dan seluruh takmir masjid baitul muttaqin masjid jambearjo ingkang kulo mulyaaken."

These italic words are the acculturation of Arabic langauge with Javanese language with each meaning is :

$$
\text { - Takmir : leader }
$$

These acculturation is from Arabic words as the original language :

$$
\text { - Takmir : Ta'mirun }
$$

\section{Datum 21 on $2^{\text {nd }}$ Transcript}

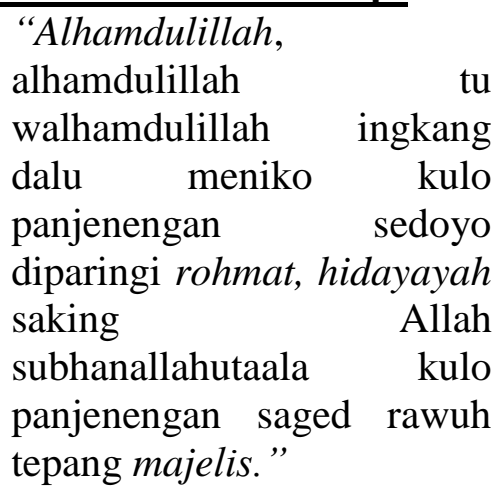

These italic words are the acculturation of Arabic langauge with Javanese language with each meanings are :
- Alhamdulillah : all praises to the God (Allah)
- Majlis : place for gathering

These acculturation is from Arabic words as the original language :

- Alhamdulillah

Alhamdulillah

- Majlis

Majlissun

Datum 22 on $2^{\text {nd }}$ Transcript

"Meniko peristiwa ingkang wajib dipun imanaken setiap orang mukmin, ono wong islam kok ora percoyo isra mi'raj iku dadi wong murtad ateges wong kafir."

These italic words are the acculturation of Arabic langauge with Javanese language with each meanings are :

- Wajib : something must be done

- Isra' Mi'raj : Muhammad's jorney from Makah to Masjidil Haram, Masjidil Aqso, and paradise.

- Murtad : leaving islam

- Kafir : deny about islam (nonmuslim)

These acculturation is from Arabic words as the original language :
- Wajib
: Wajibun
- Isra' Mi'raj : Isra' Mi'raj
- Murtad : Murtadzun
- Kafir : Kafirun

\section{Datum 23 on $2^{\text {nd }}$ Transcript}

"Monggo bareng-bareng dzikir dateng allah, bener nopo mboten buk, purun nopo mboten buk?" 
These italic words are the acculturation of Arabic langauge with Javanese language with each meaning is :

$\begin{array}{ll}\text { - Dzikir : remember to the } & \\ \text { God } & \end{array}$

These acculturation is from Arabic words as the original language :

\section{- Dzikir}

: Dzikrun

\section{Datum 24 on $2^{\text {nd }}$ Transcript}

"Nuwun sewu, ayat ten alquran seng modele isine wonte subhanalladhi niki jumlahe mboten katah."

These italic words are the acculturation of Arabic langauge with Javanese language with each meanings are :

$$
\text { - Ayat : Verse }
$$

- Alquran : Holy Kur'an

These acculturation is from Arabic words as the original language :

$$
\begin{array}{ll}
\text { - Ayat } & \text { : Ayatun } \\
\text { - Alquran } & \text { : Alqur'anu }
\end{array}
$$

\section{Datum 25 on $2^{\text {nd }}$ Transcript}

"Ono arek wedok kok ayune ngunu seh, subhanallah. Nuwun sewu, lek oleh nikmat munine nopo buk ? alhamdulillah, lek oleh musibah innalillah."

These italic words are the acculturation of Arabic langauge with Javanese language with each meanings are :

- Subhanallah : Allah the holy one

- Alhamdulillah

$$
\text { God }
$$

- Innalillah belong to God

These acculturation is from Arabic words as the original language :

- Subhanallah

Subhanallah
- Alhamdulillah

Alhamdulillah

- Innalillah

Innalillah

\section{Datum 26 on $2^{\text {nd }}$ Transcript}

'27 rajab nabi muhammad isra' dari masjidil haram ke masjidil aqsa"

These italic words are the acculturation of Arabic langauge with Javanese language with each meaning is :

$$
\text { - Rajab : Month of Islam }
$$

These acculturation is from Arabic words as the original language :
- Rajab
: Rojabun

\section{Datum 27 on $2^{\text {nd }}$ Transcript}

"nyuwun sewu opo kyai ngamuk opo muring-muring bukan hanya tersinggung sedikit saja sudah marah tersinggung hatinya marah dadi kyai dadi ustadz,"

These italic words are the acculturation of Arabic langauge with Javanese language with each meaning is :

$$
\text { - Ustadz : teacher (man) }
$$

These acculturation is from Arabic words as the original language :

$$
\text { - Ustadz : Ustadzun }
$$

\section{Datum 28 on $2^{\text {nd }}$ Transcript} "wong wedok kok meninggal dunia, sedo terus seng lanang ridho memafkan, melbu suargo."

These italic words are the acculturation of Arabic langauge with Javanese

We language with each meaning is :

$$
\text { - Ridho : willingness }
$$

These acculturation is from Arabic words as the original language :

- Ridho : Roudlotun

Datum 29 on $2^{\text {nd }}$ Transcript 
"Seng lanang orah eroh iso mbedakno nopo iku darul haid nopo niku segar kudu eroh."

These italic words are the acculturation of Arabic langauge with Javanese language with each meaning is :

- Haid : menstruation

These acculturation is from Arabic words as the original language :

\section{- Haid : Haidlan \\ Datum 30 on $2^{\text {nd }}$ Transcript \\ "Kito percaya adanya akhirat tapi kulo sampean terus nuruti hawa nafsu mboten mempersiapkan diri golek bekal sebanyak banyaknya golek bekal untuk kebahagiaan di akhirat."}

These italic words are the acculturation of Arabic langauge with Javanese language with each meaning is :

\section{- Akhirat : eternal}

These acculturation is from Arabic words as the original language :

- Akhirat : Akhirotun

\section{Datum 31 on $2^{\text {nd }}$ Transcript}

"Meniko pejahe niko persis uripe wong niku mau gelek ngelakoni kebagusan senengane hobine keapikan hobine ngelakoni amal-amal seng sholeh mangke khusnul khotimah amin allahumma amin."

These italic words are the acculturation of Arabic langauge with Javanese language with each meanings are :

- Sholeh : good

- Khusnul khotimah : die with good condition
These acculturation is from

Arabic words as the original

language :

- Sholeh

Sholikhun

- Khusnul khotimah : Khusnul khotimah

Datum 32 on $2^{\text {nd }}$ Transcript

"Ini bukti tanda muhammad

SAW bersabda man khofa sinten tiyange kok nggadah iman bener-bener sak estu dateng gusti allah maka sedoyo gusti allah gelem nulungi lan paring hidayah."

These italic words are the acculturation of Arabic langauge with Javanese language with each meaning is :

- Hidayah : God's directions These acculturation is from Arabic words as the original language :

- Hidayah : Alhidayah

Datum 33 on $2^{\text {nd }}$ Transcript

"Lek umpomo kanjeng nabi ga ngurangi nasihat e Nabi Musa sedino sewengi sembahyang e seket wektu kapan turune kapan nyambut gawene kapan nggawe arek-arek yok opo lek kate nggawe arek-arek ono adzhan dikon sembahyang betapa berjasanya Nabi Musa kepada umatipun kanjeng nabi muhammad SAW."

These italic words are the acculturation of Arabic langauge with Javanese language with each meaning is :

- Adzhan : praying call

These acculturation is from

Arabic words as the original language :

$$
\text { Adzhan : Adzan }
$$

Datum 34 on $2^{\text {nd }}$ Transcript 
"Ingkang dinten hari kiamat meniko sholat menawi dipun perikso solatipun dalam keadaan sempurna, sholatipun sae, jamaah e sregep sholat sunnah qobliyah ba'diyah kabeh dhuha ne istiqomah, solat $\mathrm{e}$ sae sedoyo amalan dipun dening gusti allah SAW pasti melok sae."

These italic words are the acculturation of Arabic langauge with Javanese language with each meanings are :

- Kiamat doomsday

- Qobliyah : before (kinds of sholat before main sholat)

- Ba'diyah : after (kinds of sholat after main sholat)

- Dhuha time

- Istiqomah consistence

- Amalan things

These acculturation is from Arabic words as the original language :

- Kiamat Qiyamatun

- Qobliyah Qobliyatin

- Ba'diyah Ba'diyatin

- Dhuha

- Istiqomah : Dluha Istiqomatun

- Amalan : 'Amalan

\section{Datum 35 on $2^{\text {nd }}$ Transcript} mboten faseh.
These italic words are the acculturation of Arabic langauge with Javanese language with each meaning is :

- Faseh : good pronunciation

These acculturation is from Arabic words as the original language :

- Faseh : Fasikhun

\section{Datum 36 on $2^{\text {nd }}$ Transcript}

"Menawi wali nikah ada yang mengesahkan ada yang tidak, lha lek syarate wali nikah koyog syarate wali loro egkok anake ga rabirabi lakan."

These italic words are the acculturation of Arabic langauge with Javanese language with each meaning is :

- Wali nikah : bride father, brother, or judge

These acculturation is from

Arabic words as the original

language :

- Wali nikah : Waliyu nikakhi

Datum 37 on $2^{\text {nd }}$ Transcript

"Jangan bicara umroh

sunnah 5 sampai 10 kali, orang sengaja meningalkan sholat satu kali meng-qodo' sholat satu kali dengan sengaja di ijoli haji sunnah peng sewu mboten saget mboten pok kangge nambeli meng-qodo' sholat tanpa sebab."

These italic words are the acculturation of Arabic langauge with Javanese language with each meanings are :

- Umroh : Arrive in Baitullah (Ka'bah, Makkah) for praying except on dzulhijah.

- Haji : Arrive in Baitullah (Ka'bah, Makkah) for praying on dzulhijah.

- Haji sunnah : Arrive in Baitullah (Ka'bah, Makkah) for 
praying on dzulhijah in second times.

- Qodo' : time of sholat replacement

These acculturation is from

Arabic words as the original language :

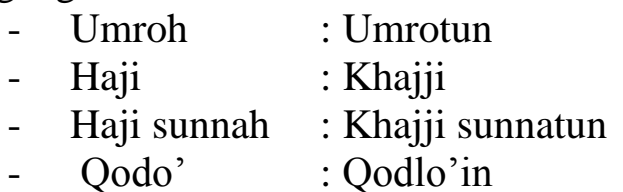

\section{Datum 38 on $2^{\text {nd }}$ Transcript}

"Syukur syukur gak lewat mboten nyicipi neroko monggoh mulai sakniki sak derenge adzan pun siap2 wudhu pun siap jamaah istirahat soko kegiatan nopo mawon. Sanggup buk ? insyallah."

These italic words are the acculturation of Arabic langauge with Javanese language with each meanings are :

- Wudhu : ritual abluton before prayer

- Insyaallah : if the God will

These acculturation is from Arabic words as the original language :

$$
\begin{array}{ll}
\text { - } & \text { Wudhu } \\
\text { - Insyaallah } & \text { : Insyallah }
\end{array}
$$

\section{Datum 39 on $2^{\text {nd }}$ Transcript}

"Sholate kulo panjenengan semangat-semangat shalat sunnah qobliyah ba'diyah tahajud e do'a e mugi-mugi sedoyo dipun terami dining gusti allah SWT."

These italic words are the acculturation of Arabic langauge with Javanese language with each meaning is :

- Tahajud : one-third night (sholat which is conducted on one third night)
These acculturation is from

Arabic words as the original

language :

- Tahajud : Tahajudin

The process of acculturation of Arabic language and javanese language is influence with how the spread of religion (Islam). Islamic is one of the big follower in Indonesia which the bound of the national language is Arabic, the javanese language adopted the arabic language because of Islamic regenerations, it means the language that people commonly used is not purely addopted with the original language (Arabic), but for addopting this language by the proces of omitting, adding, both of adding and omitting some of words, or changing all the structure of words, and no changing of words.

\section{A. Omitting some words consist of :}

1. The word "Tahajudin" in Arabic become "Tahajud" addopted by Javanese language as the acculturation which has meaning "one-third night" with omitting suffix - in.

2. The words "waliyu nikakhi" in Arabic language become "wali nikah" addopted by Javanese language as the acculturation which has meaning "bride father, brother, or judge" with ommiting suffix -yu(waliyu), khi(nikakhi).

3. The words "khajji" in Arabic become "haji" addopted by Javanese language as the acculturation which has meaning "arrive in Baitullah on Dzulijah" with ommit affix k- and ommit one letter of $\mathrm{J}$.

4. The words "qodlo'un" become "qodo" " addopted by Javanese language as the acculturation 
which has meaning "time of sholat replacement" with omitting suffix - un.

5. The words "al-hidayah" in Arabic language bcome "hidayah" addopted by Javanese language as the acculturation which has meaning "God's directions" with omitting affix al-.

6. The word "ustadzun" in Arabic language become "ustadz" addopted by Javanese language as the acculturation which has meaning "teacher(man)" with omitting suffix - un.

7. The word "ayatun" in Arabic language become "ayat" addopted by Javanese language as the acculturation which has meaning "verse" with omitting suffix -un.

8. The word "alqur'anu" in Arabic language become "alqur'an" addopted by Javanese language as the acculturation which has meaning "holy kur'an" with omitting suffix $-\mathrm{u}$.

9. The word "wajibun" in Arabic language become "wajib" addopted by Javanese language as the acculturation which has meaning "must be" with omitting suffix - un.

10. The word "murtadzun" in Arabic language become "murtad" addopted by Javanese language as the acculturation which has meaning "leaving Islam" with omitting suffix -zun.

11. The word "kafirun" in Arabic language become "kafir" addopted by Javanese language as the acculturation which has meaning "deny abot Islam" with omitting suffix -un.

12. The word "ulama' $u$ " in Arabic language become "ulama"" addopted by Javanese language as the acculturation which has meaning "religious socialite" with omitting suffix $-\mathrm{u}$.

13. The words "majlissun" in Arabic languange become "majlis" addopted by Javanese language as the acculturation which has meaning "place for gathering" with omitting suffix - un.

14. The words "ta'mirun" in Arabic languange become "ta'mir" addopted by Javanese language as the acculturation which has meaning "leader" with omitting suffix - un.

15. The words "sholatun" in Arabic languange become "sholat" addopted by Javanese language as the acculturation which has meaning "praying" with omitting suffix - un.

16. The words " 'ajjama'ah" in Arabic languange become "jama'ah" addopted by Javanese language as the acculturation which has meaning "together" with omitting affix -'a.

17. The words "sholatuttaubati" in Arabic languange become "sholat taubat" addopted by Javanese language as the acculturation which has meaning "prayig for regret an exclamation" with omitting suffix $-\mathrm{i}$.

18. The words "rokaatin" in Arabic languange become "rokaat" addopted by Javanese language as the acculturation which has meaning "number of ritual prayer" with omitting suffix -in.

19. The words "ruku'un" in Arabic languange become "ruku' " addopted by Javanese language as the acculturation which has meaning "one kinds of movement 
in praying" with omitting suffix un.

20. The words "sujudi" in Arabic languange become "sujud" addopted by Javanese language as the acculturation which has meaning "one kinds of movement in praying" with omitting suffix i.

21. The words "masjidi" in Arabic languange become "masjid" addopted by Javanese language as the acculturation which has meaning "mosque" with omitting suffix $-\mathrm{i}$.

22. The words "az-zina" in Arabic languange become "zina" addopted by Javanese language as the acculturation which has meaning "sex without marriage" with omitting affix a-.

23. The words "musyriki" in Arabic languange become "musyrik" addopted by Javanese language as the acculturation which has meaning "comporing Allah with anyone else" with omitting suffix $-i$.

24. The words "rohmatu" in Arabic languange become "rohmat" addopted by Javanese language as the acculturation which has meaning "affection" with omitting suffix $-u$.

25. The words "tafsiru" in Arabic languange become "tafsir" addopted by Javanese language as the acculturation which has meaning "an explanation/interpretation" with omitting suffix $-\mathrm{u}$.

26. The words "sya'banu" in Arabic languange become "sya'ban" addopted by Javanese language as the acculturation which has meaning "month of islam" with omitting suffix $-\mathrm{u}$.

\section{B. Omitting and adding some words} consist of :

1. The words "umrotun" in Arabic become "umroh" addopted by Javanese language as the acculturation which has meaning "arrive in Baitullah" with suffixtun replacing with suffix $-\mathrm{h}$.

2. The words "dzikrun" in Arabic languange become "dzikir" addopted by Javanese language as the acculturation which has meaning "remember the God" with omitting suffix -run replacing suffix -ir.

3. The words "khajji sunnatun" in Arabic become "haji sunnah" addopted by Javanese language as the acculturation which has meaning arrive in Baitullah in second times with ommiting affix k-, suffix -tun replacing by suffix $-\mathrm{h}$, and also remove words $\mathbf{J}$ in khajji.

4. The words "fashi'un" in Arabic become "faseh" addopted by Javanese language as the acculturation which has meaning the good pronunciation with omitting suffix -shi'un replacing with suffix-seh.

5. The words "qiyamah" in Arabic language become "kiamat" addopted by Javanese language as the acculturation which has meaning doomsday with omittting affix q- replacing with $\mathrm{k}-$, ommit suffix $-\mathrm{h}$ replacing suffix -tun, and ommit y letter on the middle.

6. The words "qobliyatin" in Arabic become "qobliyah" addopted by Javanese language as the acculturation which has 
meaning before with omitting suffix - tin replacing with suffix-h.

7. The words "ba'diyatin" in Arabic become "ba'diyah" addopted by Javanese language as the acculturation which has meaning "after" with omitting suffix - tin replacing with suffix-h.

8. The words "istiqomatun" in Arabic become "istiqomah" addopted by Javanese language as the acculturation which has meaning "consistence" with omitting suffix -tun replacing suffix $-h$.

9. The words "sholikhun" in Arabic language become "sholeh" addopted by Javanese language as the acculturation which has meaning "good" with omitting suffix -ikhun replacing suffix -eh.

10. The words "akhirotun" in Arabic language become "akhirat" addopted by Javanese language as the acculturation which has meaning "eternal" with omitting suffix - rotun replacing suffix rat.

11. The words "haidlan" in Arabic languange become "haid" addopted by Javanese language as the acculturation which has meaning "menstruation" with omitting suffix -dlan replacing suffix $-\mathrm{d}$.

12. The words "'ibadatun" in Arabic languange become "ibadah" addopted by Javanese language as the acculturation which has meaning "following order and leavng prohibition" with omitting suffix -tun replacing suffix $-\mathrm{h}$.
13. The words "dziarotun" in Arabic languange become "ziaroh" addopted by Javanese language as the acculturation which has meaning "visiting" with omitting suffix -tun replacing suffix $-\mathrm{h}$, and omiit affix D-.

14. The words "tasbikhu" in Arabic languange become "tasbeh" addopted by Javanese language as the acculturation which has meaning "tool for praying" with omitting suffix -khu replacing suffix -eh.

15. The words "sunnatun" in Arabic languange become "sunnah" addopted by Javanese language as the acculturation which has meaning "additional reward" with omitting suffix -tun reppalcing suffix $-\mathrm{h}$.

16. The words "dhuhri" in Arabic languange become "dhuhur" addopted by Javanese language as the acculturation which has meaning "prayer on midday" with omitting suffix -hri replacing suffix -hur.

17. The words "sodaqoti" in Arabic languange become "sodaqoh" addopted by Javanese language as the acculturation which has meaning "giving something to the poor in the name of Allah" with omitting suffix -ti replacing suffix $-\mathrm{h}$.

18. The words "khomru" in Arabic languange become "khomer" addopted by Javanese language as the acculturation which has meaning "kinds of beverage which intoxicate" with omitting suffix -ru replacing suffix -er.

19. The words "barokatu" in Arabic languange become "barokah" addopted by Javanese language 
as the acculturation which has meaning "blessing " with omitting suffix -tu replacing suffix - $h$.

C. Without ommitting and adding some of words because of replacing same pronunciation consists of :

1. The word "wudlu' " in Arabic become "wudhu" addopted by Javanese language as the acculturation which has meaning "ritual ablution before prayer". Arabic language has characters of "ain", "dal", "dhal" but in javanese has "a" and "d/dh", so thats why wudlu' in Arabic become wudhu in Javanese language.

2. The word "dluha" in Arabic become "dhuha" addopted by Javanese language as the acculturation which has meaning "morning time". Arabic language has characters of "dal", "dhal" but in javanese " $\mathrm{d} / \mathrm{dh}$ ", so thats why dluha in Arabic become dhuha in Javanese language.

3. The word "ramadloni" in Arabic become "ramadhan/romadhon" addopted by Javanese language as the acculturation which has meaning "holy month". Arabic language has characters of "dal", "dhal" but in javanese " $\mathrm{d} / \mathrm{dh}$ ", so thats why dlon(ramadloni) in Arabic become dhon?(ramadhon) in Javanese language with omitting suffix $-\mathrm{i}$.

\section{Change all the word structure}

1. The word "roudlotun" in Arabic language become "ridho" addopted by Javanese language as the acculturation which has meaning "the willingness".

2. The word "rojabun" in Arabic language become "rejeb" addopted by Javanese language as the acculturation which has meaning "one kinds of month in Islam".

3. The word "salamatu" in Arabic language become "slamet" addopted by Javanese language as the acculturation which has meaning "safety, salvation".

\section{E. No changing}

1. The word "insyaallah" is used by both of Arabic and Javanese as the aculturation which has meaning "if the God will"

2. The word "'amalan" is used by both of Arabic and Javanese as the aculturation which has meaning " a good things"

3. The word "adzan" is used by both of Arabic and Javanese as the aculturation which has meaning " prayer call"

4. The word "khusnul khotimah" is used by both of Arabic and Javanese as the aculturation which has meaning " die with a good conditions"

5. The word "subhanallah" is used by both of Arabic and Javanese as the aculturation which has meaning "Allah the holy one"

6. The word "alhamdulillah" is used by both of Arabic and Javanese as the aculturation which has meaning "Thank God"

7. The word "innlillah" is used by both of Arabic and Javanese as the aculturation which has meaning " we belong to God"

8. The word "isra' mi'raj" is used by both of Arabic and Javanese as the aculturation which has meaning " Muhammad's destinantion from Makkah to masjidil aqso, masjidil haram, and paradise." 
9. The word "riba" " is used by both of Arabic and Javanese as the aculturation which has meaning "interest"

10. The word "istighfar" is used by both of Arabic and Javanese as the aculturation which has meaning "make a pardon"

11. The word "nisfu sya'ban" is used by both of Arabic and Javanese as the aculturation which has meaning "nisfu is half, and sya'ban is month. Nisfu sya'ban is a half of sya'ban, means at15th day of sya'ban."

12. The word "bismillah" is used by both of Arabic and Javanese as the aculturation which has meaning "on the name of Allah."

\section{CONCLUSION}

From the data which are taken from observation, documentation, and interview people on Bululawang Malang. The researcher found the acculturation such as sholat, mesjid, riba' and the other which is explained brifery in previous chapter and the next explanation explained in form of corpuses in appendices.

From recording the pengajian, the researcher get at least about seventy words which is spoken by people in bululawang for supporting their communication. At least ten percent of pengajian purely spoken with language that contain with the acculturation of Arabic language and Javanese language. from this result the researcher summarizes that there are some of people using the acculturation. The word uses in communication is rarely used. The language the people used beside from the acculturation are Javanese language, Indonesian, Sanskrit language, and etc.

\section{SUGGESTION}

The researcher considers that this study is new at Kanjuruhan University of Malang in the langauge field especially in English Literature. The researcher suggests that it can give a description as information to the reader about acculturation between Arabic langauge and Javanese language in Malang.

The researcher suggests that the readers who want to analyze language acculturation can add the theory from other sources which are not only included in this research but also from other references.

It is suggested to the other researcher, to conduct the different research with different problems, but still dealing with the acculturation between Javanese language and Arabic langauge. Hopefully, with contribution of other researchers, may increase the heritance of defelopment language.

\section{References}

Redfield, R., Linton, R., \& Herskovits, M.J.1936.Memorandum for the study of acculturation. American Anthropologist, 38, 149-152.

Graves, T.D. 1967. Acculturation, access, alcohol in a tri-ethnic country. American Anthropologist, 59, 306-321 